\title{
Phytoplankton Growth Balanced by Clam and Zooplankton Grazing and Net Transport into the Low-Salinity Zone of the San Francisco Estuary
}

\author{
Wim J. Kimmerer • Janet K. Thompson
}

Received: 19 June 2013 / Revised: 9 October 2013 / Accepted: 2 December 2013 /Published online: 7 January 2014

(C) The Author(s) 2014. This article is published with open access at Springerlink.com

\begin{abstract}
We estimated the influence of planktonic and benthic grazing on phytoplankton in the strongly tidal, riverdominated northern San Francisco Estuary using data from an intensive study of the low salinity foodweb in 2006-2008 supplemented with long-term monitoring data. A drop in chlorophyll concentration in 1987 had previously been linked to grazing by the introduced clam Potamocorbula amurensis, but numerous changes in the estuary may be linked to the continued low chlorophyll. We asked whether phytoplankton continued to be suppressed by grazing and what proportion of the grazing was by benthic bivalves. A mass balance of phytoplankton biomass included estimates of primary production and grazing by microzooplankton, mesozooplankton, and clams. Grazing persistently exceeded net phytoplankton growth especially for larger cells, and grazing by microzooplankton often exceeded that by clams. A subsidy of phytoplankton from other regions roughly balanced the excess of grazing over growth. Thus, the influence of bivalve grazing on phytoplankton biomass can be understood only in the context of limits on phytoplankton growth, total grazing, and transport.
\end{abstract}

Keywords Potamocorbula amurensis · Bivalve ·

Microzooplankton $\cdot$ Mixing diagram

Communicated by Marco Bartoli

W. J. Kimmerer $(\bowtie)$

Romberg Tiburon Center, San Francisco State University,

3152 Paradise Drive, Tiburon, CA 94920, USA

e-mail: kimmerer@sfsu.edu

J. K. Thompson

U.S. Geological Survey, 345 Middlefield Rd. MS-496, Menlo Park, CA 94025, USA

e-mail: jthompso@usgs.gov

\section{Introduction}

Grazing exerts a dominant influence on plankton in many estuarine, coastal, and freshwater ecosystems (Cloern 1982; MacIsaac 1996; Strayer 2009). Grazing by bivalves can suppress phytoplankton blooms, increase water clarity, and reduce populations of bacteria and micro- and mesozooplankton, shunting energy from the pelagic to the benthic or littoral environments (Alpine and Cloern 1992; Werner and Hollibaugh 1993; Pace et al. 1998; Strayer 2009). Grazing by zooplankton, particularly microzooplankton, can also cause significant losses to phytoplankton (Calbet and Landry 2004).

Much of the published information on the influence of bivalve grazers on plankton has been provided by studies of sharp temporal changes, notably species introductions. An introduction provides a clear change point at which inferences about the impacts of a grazer such as a bivalve can be drawn from the contrast between conditions before and after the introduction, supplemented with estimates of grazing impact. The best-documented examples are the introduction of zebra mussels, Dreissena polymorpha, throughout North America (MacIsaac 1996; Strayer 2009) and the introduction of the "overbite" clam Potamocorbula amurensis to the San Francisco Estuary (Alpine and Cloern 1992; Thompson 2005; Kimmerer 2006). These examples are compelling because the introductions occurred in locations with long-term monitoring programs capable of assessing ecosystem responses (e.g., Pace et al. 1998; Jassby 2008). Examples with other species show overwhelming impacts of bivalve grazing on the water columns of shallow lakes and estuaries through introductions (e.g., Corbicula fluminea, Phelps 1994) or removal (e.g., Mya arenaria, Beukema and Cadee 1996).

By contrast, most zooplankton introductions have resulted in rather subtle changes in extant plankton assemblages (e.g., Gorokhova et al. 2005; Cordell et al. 2008). The chief exceptions are introductions of gelatinous predators such as 
Mnemiopsis leidyi into the Black Sea, which appeared to precipitate a trophic cascade (Daskalov et al. 2007).

The responses described in the bivalve examples above were strong and nearly simultaneous to the respective invasions and could be treated as step changes. However, postinvasion variation in bivalve abundance, zooplankton grazing, or other factors cause ongoing variability in the bivalve's impact (e.g., Thompson 2005; Caraco et al. 2006; Cloern et al. 2007, Fishman et al. 2009). Even when care is taken to account for potentially confounding influences (e.g., Pace et al. 1998), an analysis treating an invasion as a change point in a time series may rest on rather weak statistical grounds unless spatial contrasts can be exploited to distinguish the signal due to the introduction from other temporal variability (e.g., Strayer 2009).

Aquatic ecosystems, particularly rivers and estuaries, are under continual perturbation by natural and anthropogenic forcing, some with trends that can mimic the effects of grazing. In the northern, river-dominated San Francisco Estuary (SFE), many inputs and ecosystem characteristics have undergone trends and step changes (e.g., Jassby 2008; Thomson et al. 2010; Schoellhamer 2011). Determining the ongoing influence of native or invasive grazers in the context of such a web of system-wide temporal trends must rely on more than a comparison of pre- and post-invasion conditions and negative correlations between grazer biomass and phytoplankton biomass.

Estimating the effects of grazers on the pelagic foodweb is complicated by variable influences on phytoplankton growth rate (e.g., nutrients, turbidity) and accumulation of biomass and, in rivers and estuaries, the movement of the water. In a river-dominated estuary with strong tides and complex bathymetry, the bidirectional velocity of water greatly exceeds that due to river flow and the bathymetry enhances mixing, ruling out the elegant mass balance approach used by Caraco et al. (1997) to estimate the grazing impact of zebra mussels in the Hudson River. Tidal mixing and advection can stretch the impact of benthic grazing far to landward and seaward of the range of the bivalve population (Jassby 2008) and can transport phytoplankton from areas favorable to blooms to unfavorable areas, resulting in high biomass where a bloom would be unlikely (e.g., because of poor light penetration in deep water, Lucas et al. 1999). Although studies of grazing and tidal mixing in small areas or small estuaries can provide valuable insights (e.g., Lopez et al. 2006; Nielsen and Maar 2007, Lonsdale et al. 2009), the parameters needed for similar studies are difficult to estimate at the scale of a large estuary. We are aware of no previously published study that determines the balance among phytoplankton growth, grazing by bivalves and zooplankton, and hydrodynamic gains and losses in a large, strongly tidal estuary.

This paper examines the role of grazing in limiting the development of phytoplankton blooms during spring-autumn in northern SFE. This is part of a larger study of pelagic foodweb dynamics in this region of the estuary (York et al. 2011; Kimmerer et al. 2012), prompted by its importance as the rearing habitat for the endangered and declining delta smelt, Hypomesus transpacificus (Sommer et al. 2007). We present an analysis of grazing by the bivalves $P$. amurensis and $C$. fluminea (introduced to SFE in $~ 1945$ ) on the phytoplankton of the low-salinity zone in the context of concurrent measurements of phytoplankton production and grazing by microzooplankton and mesozooplankton.

Of the various approaches available for estimating losses of phytoplankton to benthic grazing, the only suitable one is to calculate the local mass balance of phytoplankton biomass as the sum of the production and loss terms. We complemented this approach by estimating flux into the low-salinity zone from distributions of phytoplankton biomass with respect to salinity. We also analyzed long-term bivalve monitoring data in conjunction with a simplified estimate of phytoplankton growth and grazing losses to determine if the patterns observed in the long-term data were consistent with what we observed in 2006-2008.

\section{Methods}

\section{Study Site}

The northern San Francisco Estuary (SFE, Fig. 1) is a riverdominated estuary with highly variable river flows and a long summer-autumn dry season. Mean absolute tidal current speed near the study area during the dry season is about $40 \times$ the net river-derived speed. This study focused on the lowsalinity zone (LSZ, salinity $\sim 0.5-5$ ). The distance up the axis of the estuary to the approximate center of the LSZ at a salinity of 2 ("X2") has been used in previous analyses and is used in management of freshwater flows (Jassby et al. 1995). The LSZ is usually found in Suisun Bay, a broad complex of shoals and channels with a mean depth around $5 \mathrm{~m}$, and in the western California Delta (Fig. 1). In Suisun Bay, the water column is usually well-mixed, and most zooplankton species are distributed throughout the water column (Kimmerer et al. 2002).

The clam P. amurensis (=Corbula amurensis, Huber 2010) is abundant in brackish to saline water, with an annual cycle of abundance, reproduction, and settlement (Thompson 2005). This clam was introduced from Asia, became very abundant in summer 1987, and has been abundant in at least some regions of the northern estuary ever since. Despite its hypothesized strong effect on phytoplankton biomass (Alpine and Cloern 1992), it has had no detectable effect on turbidity, which is mostly due to suspended sediments rather than organic matter in this system. C. fluminea has been abundant in the freshwater Delta since the 1940 s. It too can have a strong influence on 
Fig. 1 Map of the upper San Francisco Estuary with the 10-m isobath (gray). Long-term monitoring stations indicated by diamonds (IEP) or triangles (USGS), with open triangles indicating stations sampled only in 2006-2007. Straight lines indicate boundaries of spatially intensive monitoring (thin dashed line) and median positions of samples taken in spring and summer of 2006 (thick solid) and 2007 (thick dashed). The curved line in the Delta shows locations of transects run in 2008

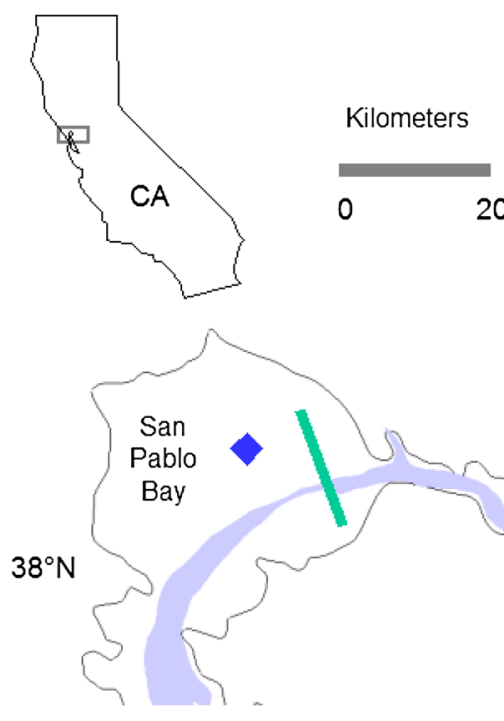

the accumulation of phytoplankton biomass in shallow freshwater areas (Lopez et al. 2006). The distributions of the two clams overlap near the transition from fresh to brackish water.

\section{Overview of Approach}

A mass balance of phytoplankton biomass within the lowsalinity zone was calculated to infer net gains or losses that must be balanced by tidal dispersion, advection, burial, or a secular trend in biomass. The mass balance took the form:

$\frac{\partial B}{\partial t}=(\mu-g) B+\Phi$,

$\mu=\frac{P}{B H}-\frac{R}{B}$,

$g=\left(g_{\mathrm{m}}+g_{\mathrm{z}}+\frac{G_{\mathrm{c}}}{H}\right)$

$\Phi \approx\left(-u \frac{\partial B}{\partial x}+K_{\mathrm{h}} \frac{\partial^{2} B}{\partial x^{2}}\right) \frac{D}{V}$

where $B$ is biomass $\left(\mathrm{mgC} \mathrm{m}{ }^{-3}\right), t$ is time (d), $\mu$ is net growth rate of phytoplankton $\left(\mathrm{d}^{-1}\right), g$ is grazing $\left(\mathrm{d}^{-1}\right), \Phi$ is the net hydrodynamic flux into the $\mathrm{LSZ}\left(\mathrm{mgC} \mathrm{m}^{-3} \mathrm{~d}^{-1}\right), P$ is production $\left(\mathrm{mgC} \mathrm{m}^{-2} \mathrm{~d}^{-1}\right), R$ is respiration $\left(\mathrm{mgC} \mathrm{m}^{-3} \mathrm{~d}^{-1}\right), H$ is water depth $(\mathrm{m})$, subscripts $\mathrm{m}$ and $\mathrm{z}$ indicate grazing by microzooplankton and mesozooplankton, respectively, and $G_{\mathrm{c}}$ is combined grazing by the two clams $\left(\mathrm{m}^{3} \mathrm{~m}^{-2} \mathrm{~d}^{-1}\right.$ or $\mathrm{m}$ $\mathrm{d}^{-1}$ ). The two terms for $\Phi$ in parentheses in Eq. 4 represent one-dimensional advection and dispersion along the axis of the estuary, where $u$ is the tidally averaged velocity $\left(\mathrm{m} \mathrm{s}^{-1}\right)$, $K_{\mathrm{h}}\left(\mathrm{m}^{2} \mathrm{~s}^{-1}\right)$ is a longitudinal dispersion coefficient, $D$ is the number of seconds in a day, $V$ is the volume of the $\operatorname{LSZ}\left(\mathrm{m}^{3}\right)$, and $x(\mathrm{~m})$ is positive landward.

Details for each term are presented below. The water column was assumed to be well-mixed vertically, which was the case for most of our field study (Kimmerer et al. 2012). Net burial of phytoplankton was assumed negligible because turnover between deposited and suspended sediments is rapid and this region has been losing erodible sediment (Schoellhamer 2011). We assumed the secular trend of phytoplankton biomass (Eq. 1) to be negligible compared to the other terms, which is consistent with the lack of strong seasonal trends in biomass within the LSZ; $90 \%$ of the calculated absolute rates of change of chlorophyll between successive monthly monitoring surveys (see below) were $<3 \% \mathrm{~d}^{-1}$. The "local" terms $\mu, g$, and $G_{\mathrm{c}}$ were used to estimate the net gains or losses within the LSZ that had to be balanced by the net flux $\Phi$ at steady state.

Production and losses of phytoplankton in the LSZ were calculated using data collected during spring (March-May) and summer (June-September) 2006 and 2007 and July 2008. These years contrasted in hydrology: March-September 2006 had the second highest freshwater flow since 1955, while 2007 and 2008 were in the 34th and 25th percentiles, respectively, of freshwater flow. Calculations were stratified into two depth zones, 0-5 m (shoal) and $>5 \mathrm{~m}$ (channel), because growth and loss processes depend strongly on water depth. 
Water depth at mean sea level $H$ was determined from a bathymetry data set at $10 \mathrm{~m}$ resolution (http://sfbay.wr.usgs. gov/sediment/delta/downloads.html; accessed $28 \mathrm{March}$ 2013). The grid cells were subsampled at $50 \mathrm{~m}$ resolution and a hypsograph was calculated.

Primary production was determined by Kimmerer et al. (2012). Two alternative estimates were made of grazing by microzooplankton. Mesozooplankton grazing was calculated from copepod growth and reproduction rates. Grazing by clams was estimated from biomass determined in seven spatially intensive surveys, supplemented with monthly monitoring data, using previously determined biomass-specific grazing rates. We calculated net production or consumption in each depth zone and combined the two to obtain overall net production in the LSZ. We also calculated net flux $\Phi$ from mixing diagrams based on three sets of closely spaced chlorophyll samples taken along the channel axis in July 2008. Finally, we expanded the temporal scope of the study by calculating phytoplankton mass balance using long-term monitoring data for chlorophyll from 1971 to 2008 and for clam biomass from 1988 to 2008 .

\section{Phytoplankton Production and Losses}

Phytoplankton biomass and primary productivity were measured as previously reported (Kimmerer et al. 2012) in 114 samples taken during 2006 and 2007 in tidal channels at surface salinities of $0.5,2$, and 5 and three samples in 2008 at salinity 2 . Measurements were made by ${ }^{14} \mathrm{C}$ uptake in simulated in situ incubations on shore at the Romberg Tiburon Center. Samples were collected after incubation on GF/F filters ("whole water") and on $5 \mu \mathrm{m}$ Nuclepore filters ( $>5 \mu \mathrm{m}$ size fraction) for ${ }^{14} \mathrm{C}$ measurement. Incubations lasted $6 \mathrm{~h}$ in 2006 and $24 \mathrm{~h}$ in 2007, and the 2006 results were adjusted to $24 \mathrm{~h}$ by the ratio of day length to $6 \mathrm{~h}$. Values were assumed to be gross production less photosynthesisdependent respiration (Jassby et al. 2002). Phytoplankton biomass was determined as chlorophyll a measured by extracted fluorometry and as carbon by gross taxonomic group from direct counts and measurements of cells (Lidström 2009; Kimmerer et al. 2012). Net primary production was calculated for each $0.1-\mathrm{m}$ depth band in the hypsograph, assuming a biomass-specific respiration rate of $15 \% \mathrm{~d}^{-1}$ (Jassby et al. 2002).

Extinction coefficient was corrected for higher turbidity over shoals using measurements of secchi depth taken in Suisun Bay by various monitoring programs during MarchAugust of 1980-2009. Surveys were selected that had at least two shoal and two channel, which resulted in 321 surveys with an average of 12 samples per survey, about half from shoal stations. Extinction coefficients, calculated as 1.24/ secchi depth (m, Kimmerer et al. 2012) were on average $14 \%$ higher over shoals than in channels, and this value was used to estimate primary production over shoals from that measured in the channels during 2006-2007. Although wind waves resuspend erodible sediment (Schoellhamer 2011), we found no detectable effect of wind speed measured at nearby meteorological stations (http://www.cimis.water.ca.gov/) on the relationship between extinction coefficients in deep vs. shallow water. In addition, there was no consistent difference in chlorophyll concentration between deep and shallow stations in the long-term monitoring data (data source described below).

\section{Zooplankton Grazing Rates}

Microzooplankton biomass and grazing on phytoplankton were determined in dilution experiments during some of our sampling events in 2006-2008 (York et al. 2011). A linear model was fitted to the data, yielding

$g_{\mathrm{m}}=\max [0,-0.3+(0.93 \pm 0.18) \mu]$

where $g_{\mathrm{m}}$ is the microzooplankton grazing rate $\left(\mathrm{d}^{-1}\right)$ and $\mu$ is the phytoplankton growth rate $\left(\mathrm{d}^{-1}\right)$, and the error term is the $95 \%$ confidence limit. As an alternative we used a value of $g_{\mathrm{m}}: \mu$ of 0.6 for estuaries from a review of dilution experiments (Calbet and Landry 2004).

Grazing by mesozooplankton, comprising copepodite and adult stages of copepods, was estimated from data on growth and reproduction rates of common copepods assuming a gross growth efficiency of $30 \%$ which is a typical figure for similar copepods at low food concentrations (Straile 1997; Calliari et al. 2006; Almeda et al. 2012). Data for specific growth and egg production rates were taken on 36 of the 43 sampling dates for the numerically dominant cyclopoid Limnoithona tetraspina (Gould and Kimmerer 2010). Data for abundant calanoid copepods were available on 37 dates for specific egg production and 13 dates for specific growth rate (Kimmerer et al. 2013). Data were interpolated linearly or extrapolated as a constant to other dates. Feeding by L. tetraspina and other copepods that feed as raptors (Bouley and Kimmerer 2006) was apportioned among motile phytoplankton and microzooplankton. Most of the other copepods were assumed to feed equally on phytoplankton $>5 \mu \mathrm{m}$ and microzooplankton. Feeding rates on phytoplankton $<5 \mu \mathrm{m}$ were assumed to be negligible. Feeding by nauplii was included in the microzooplankton feeding rate.

Benthic Abundance, Biomass, and Filtration Rate

Clam abundance and biomass were determined in long-term monthly and seasonal spatially intensive surveys conducted from January 2006 through December 2008. Triplicate benthic grabs were collected monthly from each of seven stations 
sampled by the U.S. Geological Survey (USGS) and three by the Interagency Ecological Program (IEP) in the northern estuary (Fig. 1). In March, July, and September of 2006 and 2007 and July of 2008, an additional 56 stations were sampled with single grabs throughout the Suisun Bay complex. Stations were established to sample a variety of habitat types based on depth, distance from channels, and sloughs vs. open water. All samples were collected with a $0.05-\mathrm{m}^{2}$ van Veen grab, sieved on a 0.5 -mm screen, fixed in $10 \%$ formaldehyde, and transferred to $70 \%$ ethanol stained with Rose Bengal. A subsample of live bivalves was collected from each habitat to estimate weight as a function of length; clams were measured (shell length, mm), dried, weighed, ashed, and reweighed to determine ash-free dry weight (AFDW). Bivalves in preserved samples from each habitat were measured and tissue AFDW was estimated from length-weight regressions for that habitat.

Laboratory filtration rate estimates were converted to grazing rate following Thompson et al. (2008). The filtration rate of $P$. amurensis had been estimated in flume experiments at $15{ }^{\circ} \mathrm{C}$ using Rhodomonas (=Chroomonas) salina as food (Cole et al. 1992). This phytoplankton species measures about $7 \times 10 \mu \mathrm{m}$ and is large enough to be filtered efficiently by P. amurensis (Werner and Hollibaugh 1993). Eight measurements were made at several velocities; no effect of velocity was noted, but one value was anomalously low; we therefore calculated a trimmed mean of 383 \pm 1011 (g AFDW) $)^{-1} \mathrm{~d}^{-1}$ after dropping the highest and lowest values. Other estimates of filtration rate by $P$. amurensis are in the same range (Werner and Hollibaugh 1993; Greene et al. 2011).

Experiments on thermal effects on filtration by $P$. amurensis have not been conducted. We used the model of Larsen and Riisgard (2009) with an exponent of -1.5 to viscosity, equivalent to a $Q_{10}$ of about 1.5 , to estimate filtration rate at other temperatures. Data on grazing rate of $P$. amurensis freshly collected from the field (Tables 2 and 5 in Greene et al. 2011) gave a $Q_{10}$ of about 2.2, and the beat frequency of cilia of Corbula gibba had a $Q_{10}$ of 2 to 3 (Jorgensen and Ockelmann 1991). To account for the uncertainty of the thermal effect, we used a $Q_{10}$ of 1.5 and repeated all calculations of grazing by $P$. amurensis using an alternative $Q_{10}$ of 2 .

Temperature-dependent filtration rate of $C$. fluminea was determined at four temperatures using three cultured phytoplankton species (Foe and Knight 1986). An exponential model fitted to those data was used to determine biomassspecific filtration in the field; the $Q_{10}$ estimated from this model was 3.5.

\section{Model for Bivalve Grazing}

Benthic grazing can produce a depletion boundary layer that depends on the balance between removal of cells by grazing and addition of cells by mixing and sinking (O'Riordan et al. 1995; Lucas et al. 1998). The effect of a depletion boundary layer was calculated from the experimental data and model of O'Riordan et al. (1995). The asymptotic refiltration fraction $n_{\max }$ over a bed of clams is a function of three dimensionless ratios: the ratio of spacing of clams to siphon diameters, $S / d_{0}$, the ratio of height above the bed to the diameter of clam siphons $h_{\mathrm{s}} / d_{0}$, and the velocity ratio (VR) of jet velocity of the clam siphons to shear velocity of the water. The latter two terms can be determined only for specific cases and are unknown and variable in the field. Figure 7 in O'Riordan et al. (1995) indicates a central value for $n_{\max }$ of $2 d_{0} / S$. This value results in a conservative estimate of grazing since most of the values in that figure are $<2 d_{0} / S$ for clams with siphons extended, as is usually the case for P. amurensis. However, grazing rate was insensitive to $n_{\text {max }}$ : alternative values of $n_{\max }=d_{0} / S$ or $n_{\max }=3 d_{0} / S$ resulted in a median change in the grazing rate of only $\pm 5 \%$.

The field filtration rate was calculated for each station as:

$$
\begin{aligned}
& G_{\mathrm{c}}=G_{\mathrm{b}} B_{\mathrm{c}} f\left(1-0.02 d_{0} \sqrt{A f}\right) \\
& f=\tau \varepsilon
\end{aligned}
$$

where $G_{\mathrm{c}}$ is clam grazing rate in the field $\left(\mathrm{m} \mathrm{d}^{-1}\right), G_{\mathrm{b}}$ is temperature-corrected biomass-specific grazing rate $\left(\mathrm{m}^{3} \mathrm{~g}^{-1} \mathrm{~d}^{-1}\right), B_{\mathrm{c}}$ is clam biomass ( $\mathrm{g}$ AFDW $\left.\mathrm{m}^{-2}\right), f$ is a dimensionless correction factor for filtering of clams, $d_{0}$ is the diameter of clam siphons $(\mathrm{cm})$ estimated from the median size of clams for each date at each station, and $A$ is abundance $\left(\mathrm{m}^{-2}\right)$. The correction factor $\mathrm{f}$ comprises two parts: $\tau$ is the fraction of clams assumed to be filtering at any time (default value was 0.67 based on field experiments, Thompson 1999), and $\varepsilon$ is the efficiency of filtration, which was assumed to be 1 for phytoplankton larger than $\sim 5 \mu \mathrm{m}$ and 0.75 for smaller phytoplankton based on a $28 \%$ grazing efficiency of $10 \mathrm{~mm}$ clams grazing on $\sim 1 \mu \mathrm{m}$ bacteria relative to grazing on phytoplankton $>5 \mu \mathrm{m}$ (Werner and Hollibaugh 1993).

Grazing rate was extrapolated to field populations by a stratified approach in which channels ( $>5 \mathrm{~m}$ depth) and shoals $(<5 \mathrm{~m})$ were treated separately. This separated the benthic samples from the spatial surveys into two approximately equal parts, and about half of the area of the LSZ was included in each depth zone. Stratification at finer resolution (e.g., by habitat type) was not feasible because of a lack of spatial resolution in possible habitat descriptors such as sediment size and because the sediment types used as habitat by these bivalves are not well defined.

The rate of loss of phytoplankton to clam grazing $\left(\mathrm{d}^{-1}\right)$ was calculated as $G_{\mathrm{c}} / H$ (Eq. 4) for the following conditions: each benthic survey, shoal vs. channel, small vs. large cells, 
alternative $Q_{10}$ values for grazing by $P$. amurensis, and various fractions of the clams filtering at a time $(\tau)$.

Analyzing the influence of grazing by stationary bivalves on plankton is complicated by the movement of the overlying water. In particular, under high-flow conditions, the LSZ is moved seaward of the area where the benthos was sampled. For each benthic survey, we estimated an up-estuary limit of the LSZ from the position of the 2-psu isohaline along the axis of the estuary (Jassby et al. 1995). To this position, we added the mean distance between 2 and 0.5 psu determined as the distance obtained by interpolating salinity from five continuous monitoring stations in Suisun Bay $(9 \mathrm{~km})$, and half the tidal excursion distance in Suisun Bay $(11 \mathrm{~km}$; Kimmerer et al. 2002). For each benthic survey, only the sampling stations seaward of this limit were included in the analysis. The hypsograph for each survey was calculated using all 50-m grid cells between this limit and the western margin of Suisun Bay.

\section{Data for Flux Estimate}

In July 2008, we sampled for chlorophyll along three transects from the LSZ into freshwater along the Sacramento River (Fig. 1) and measured primary production in the LSZ as in 2006-2007. These data were analyzed as above, except that phytoplankton species composition was not determined and chlorophyll was not fractionated by size. We set the $\mathrm{C} / \mathrm{Chl}$ ratio to 23 for total chlorophyll as determined in 2007 (Kimmerer et al. 2012) and estimated mesozooplankton grazing as the mean of values from 2007, a similarly dry year.

The transect data were used to develop mixing diagrams as plots of chlorophyll vs. salinity (Officer and Lynch 1981) to estimate net flux of phytoplankton biomass into the LSZ ( $\Phi$ in Eq. 1). A concave-up mixing diagram indicates local net consumption, and a concave-down mixing diagram indicates a combination of local net production and lateral sources, e.g., from adjacent marshes or wastewater discharges. The most likely lateral source is Suisun Marsh north of Suisun Bay, but its long residence time ( $\sim 3$ weeks, Culberson et al. 2004) means that this source is minor. Neglecting lateral sources, we calculated the net flux $\Phi\left(\mathrm{d}^{-1}\right)$ into the LSZ (Officer and Lynch 1981, Kimmerer 2005):

$\Phi=\frac{\left(y_{1}-y_{2}\right) Q}{V C}$

where $Q$ is freshwater flow $\left(\mathrm{m}^{-3} \mathrm{~d}^{-1}\right), V$ is volume of the LSZ from the hypsograph $\left(\mathrm{m}^{3}\right)$, and $C$ is mean chlorophyll concentration at salinity 0.5 to 5 . The terms $y_{1}$ and $y_{2}$ are the zero intercepts of lines tangent to the curve of chlorophyll at the landward $\left(y_{1}\right)$ and seaward $\left(y_{2}\right)$ margins of the LSZ. Freshwater flow $Q$ was the net Delta outflow (http://www.water.ca. gov/dayflow) averaged over the month ending on July 11 (the midpoint of the sampling dates). The intercept $y_{2}$ was determined by linear regression of chlorophyll on salinity for $S>1.5$, i.e., the four high salinity data points that surrounded $S=5$. Chlorophyll had a maximum at $S$ between 0.1 and 0.3 , so $y_{1}$ was determined using data at $S<3$ but excluding points at $S$ below which chlorophyll was less than $90 \%$ of its peak value; $y_{1}$ was insensitive to alternative choices of limits. Variances of intercepts were used to propagate error and obtain confidence intervals for $-\Phi$, which by Eq. 1 at steady state is equal to net production in the LSZ.

\section{Long-Term Monitoring Data for Temporal Context}

We calculated monthly phytoplankton growth and grazing losses from long-term monitoring by the Interagency Ecological Program (IEP) has sampled throughout the northern estuary monthly for salinity, chlorophyll, and turbidity (since 1969) and abundance of mesozooplankton (1972) and benthos (1977) (Orsi and Mecum 1986; Peterson and Vayssières 2010). Primary production has already been calculated from the long-term data (Kimmerer et al. 2012). Microzooplankton grazing was estimated as described above, and mesozooplankton (copepod) grazing was estimated using the mean clearance rates of copepods calculated from the grazing rate estimates from 2006 and 2007 and whole chlorophyll converted to carbon as above. Triplicate benthic samples have been taken by USGS and IEP monthly (with some gaps) since 1988, and we obtained biomass estimates as described above for $P$. amurensis from three shoal and four channel stations in Suisun Bay and one station in San Pablo Bay, and for $C$. fluminea from the easternmost station where it was often abundant (Fig. 1). Data for San Pablo Bay were used as a check on grazing rates, because the LSZ was in San Pablo Bay during high-flow periods such as in spring 2006. Clam biomass for 2003 was unavailable, so it was estimated from a $\log -\log$ regression of biomass on number of clams by month in other years.

Bivalve grazing rates from long-term stations in Suisun Bay during 2006 and 2007 were closely correlated with values from concurrent spatially intensive sampling ( $r=$ 0.95 for shoals and 0.96 for channels). However, the ratio of median grazing rate in the spatially intensive data to that from the long-term data from the same months was 0.39 for channels and 1.41 for shoals (see "Results," Fig. 2), indicating that the long-term stations were not fully representative of the spatially intensive stations. We used these median ratios to adjust calculated grazing rates from the long-term data before data from the two depth zones were combined.

Long-term monitoring data for chlorophyll from 1971 to 2010 were also used to infer the sign and gross magnitude of net production in the LSZ. We pooled data from the water 
Fig. 2 a-h Data used in determining phytoplankton mass balance in 2006 and 2007 for small $(<5 \mu \mathrm{m})$ and large $(>5 \mu \mathrm{m})$ size classes in shoals $($ depth $<5 \mathrm{~m})$ and channels $(>5 \mathrm{~m})$. Circles, growth less total zooplankton grazing from intensive field study in 2006-2007; triangles, clam grazing rates from spatially intensive surveys; solid line, clam grazing rates based on monthly monitoring data; dotted line, clam grazing rate from monitoring station in San Pablo Bay in 2006 (see "Methods"). Clam grazing assumes $Q_{10}=1.5, \tau=0.67$, and $\varepsilon=1$ for large cells and 0.75 for small cells

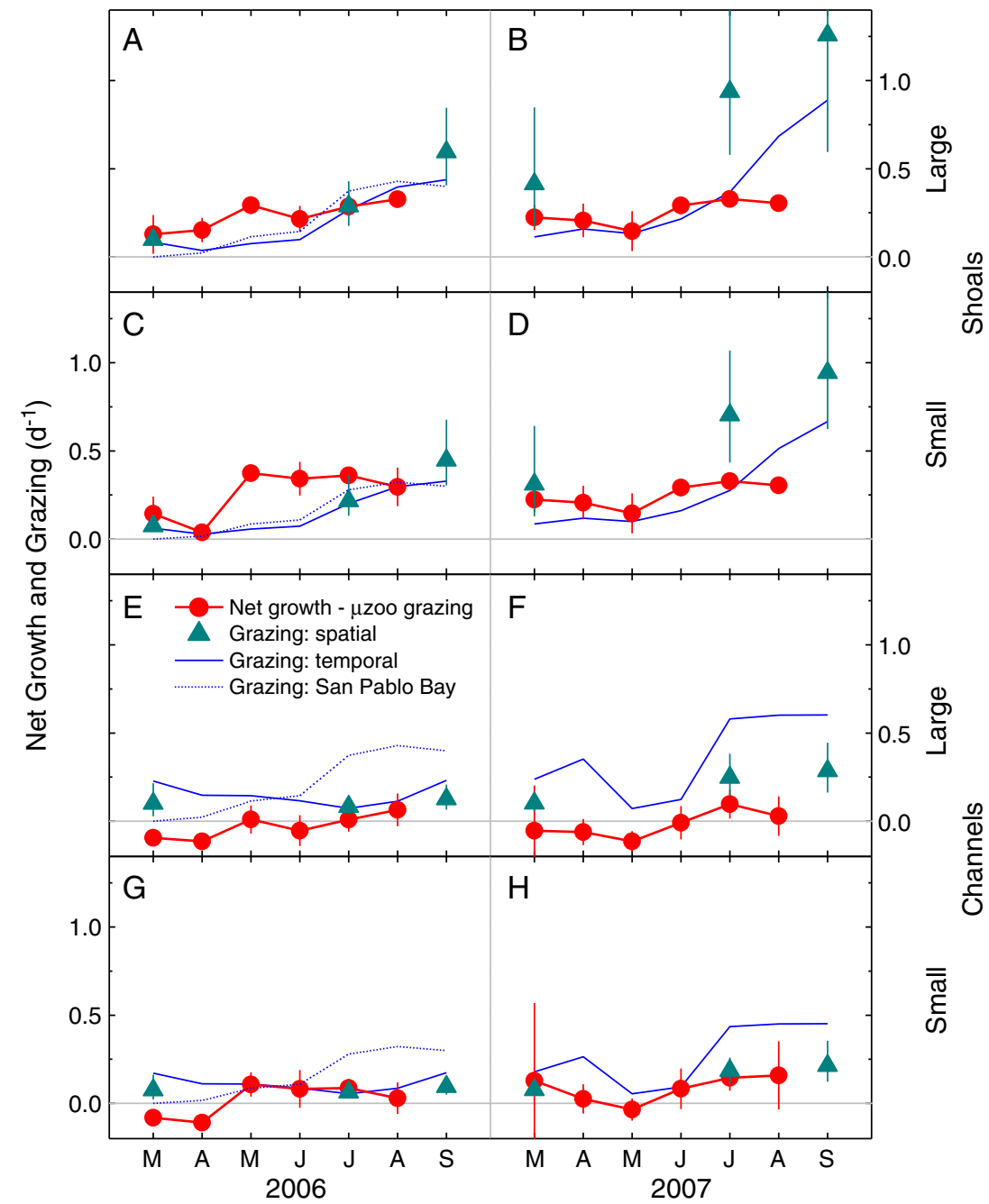

quality and zooplankton monitoring programs. Stations from the southeastern Delta were excluded because salinity there is often elevated by saline agricultural return flow. Plots of chlorophyll vs. log of salinity were smoothed using a generalized additive model with a cubic spline smoother with 4 degrees of freedom, a log link function, and variance proportional to mean squared (Hastie and Tibshirani 1990). Smoothed curves were used to develop image plots of chlorophyll vs. year and salinity for 2-month periods from March through October.

\section{Results}

Phytoplankton Growth and Grazing

Specific growth rates of phytoplankton were near zero in the channels and higher over the shoals (Table 1). The relatively large confidence intervals around the seasonal means arose from variability within seasons and among the three salinity stations. Growth rates of the two size classes of phytoplankton were similar (Table 1).

Microzooplankton grazing rate, whether estimated from a relationship determined during this study or from the literature, was a substantial fraction of phytoplankton growth rate in shoals but not in channels, where net phytoplankton growth rate was low (Table 1, and see Eq. 5). Mesozooplankton grazing on the large $(>5 \mu \mathrm{m})$ size fraction of phytoplankton was generally smaller than that of microzooplankton over shoals (Table 1), and we have assumed it to be negligible for smaller phytoplankton. Because mesozooplankton abundance and therefore presumably grazing does not vary much between deep and shallow water, grazing by mesozooplankton in the channels was higher than that of microzooplankton. Seasonal patterns of net phytoplankton growth less combined grazing by micro- and mesozooplankton (Fig. 2) were not strong, except for low or even negative net growth during spring.

Mean clam abundance varied between 150 and 6,560 individuals $\mathrm{m}^{-2}$, and mean biomass between 2 and $7 \mathrm{~g}$ AFDW $\mathrm{m}^{-2}$ (Table 2). Clams were generally larger in spring and summer 2006 than in 2007 or 2008; an autumn recruitment 


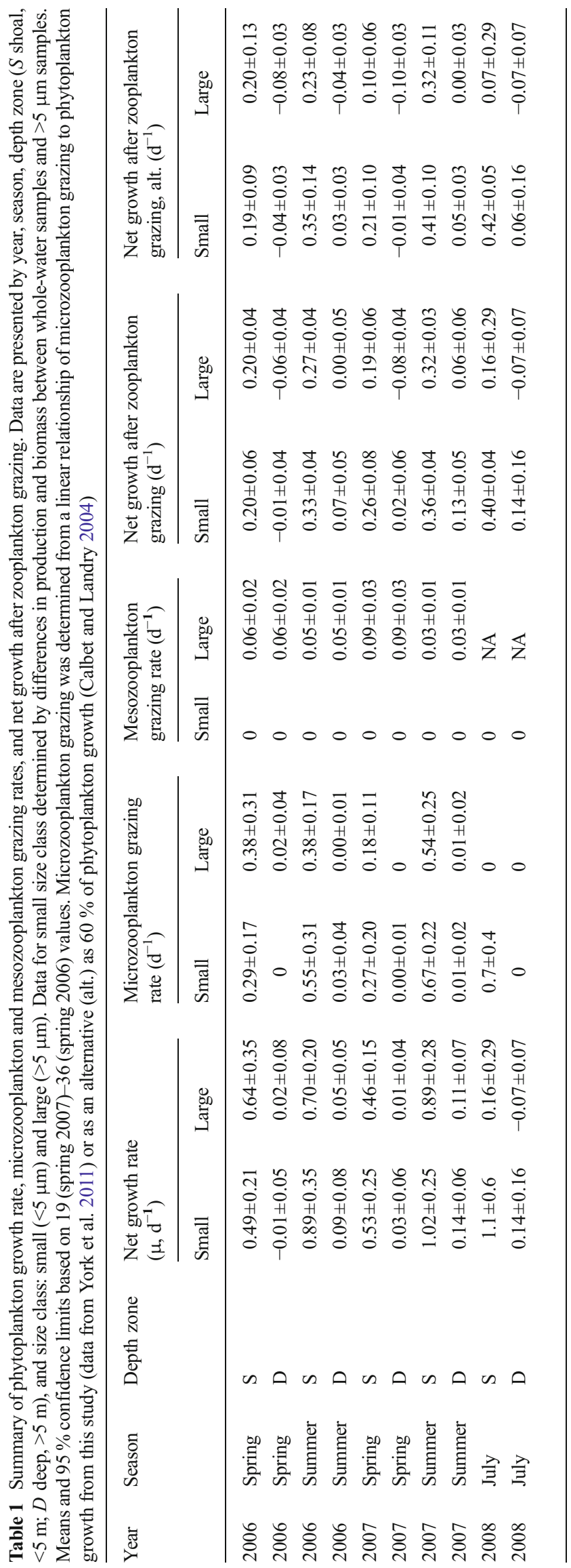


Table 2 Summary of spatially intensive surveys of clam biomass during 2006-2008. The number and biomass of Potamocorbula amurensis and Corbicula fluminea have been combined for this table

\begin{tabular}{|c|c|c|c|c|c|c|c|c|c|}
\hline \multirow[t]{2}{*}{ Year } & \multirow[t]{2}{*}{ Month } & \multicolumn{2}{|c|}{ Number of stations } & \multicolumn{2}{|c|}{ Mean (clams m ${ }^{-2}$ ) } & \multicolumn{2}{|c|}{ Mean $\left(g_{\text {AFDW m}}^{-2}\right)$} & \multicolumn{2}{|c|}{ Mean (mg AFDW clam $\left.{ }^{-1}\right)$} \\
\hline & & Shallow & Deep & Shallow & Deep & Shallow & Deep & Shallow & Deep \\
\hline 2006 & March & 54 & 62 & 330 & 480 & 1.8 & 3.7 & 5 & 8 \\
\hline 2006 & July & 52 & 60 & 150 & 220 & 2.5 & 2.3 & 17 & 11 \\
\hline 2006 & September & 52 & 58 & 6,560 & 1,590 & 3.8 & 2.9 & 1 & 2 \\
\hline 2007 & March & 52 & 58 & 1,930 & 2,080 & 3.6 & 3.2 & 2 & 2 \\
\hline 2007 & July & 52 & 56 & 2,020 & 1,480 & 6.5 & 5.2 & 3 & 4 \\
\hline 2007 & September & 52 & 58 & 2,350 & 1,420 & 5.7 & 7.0 & 2 & 5 \\
\hline 2008 & July & 52 & 58 & 2,650 & 960 & 3.4 & 3.6 & 1 & 4 \\
\hline
\end{tabular}

event between July and September 2006 resulted in a smaller mean size in autumn 2006 than in autumn 2007. Clams tended to be larger in deep water than in shallow, so that the mean ratio of AFDW clam ${ }^{-1}$ in deep water to that in shallow water was $2.7 \pm 2.0(95 \% \mathrm{CI})$. Biomass in 2007 was about twice that in 2006 .

Clam grazing rates increased through the study periods of 2006 (shoals only) and 2007 (shoals and channels), as shown by both the spatially intensive surveys and monthly monitoring (Fig. 2). Between 70 and $94 \%$ of bivalve grazing estimated from spatially intensive data was by $P$. amurensis. Grazing rates of $P$. amurensis estimated using an alternative $Q_{10}$ of 2 differed by between -10 and $+23 \%$ from values estimated using the selected value of 1.5 , depending on temperature; since this difference did not affect conclusions, the latter value was used in all subsequent calculations. Long-term monitoring data from the San Pablo Bay shoals (LSZ was in San Pablo Bay in spring of 2006 only) showed similar grazing rates and a similar seasonal pattern to data from Suisun Bay shoals (Fig. 2). Total grazing by bivalves and micro- and mesozooplankton equaled or exceeded phytoplankton growth at all times in channels, and at all times except during AprilJune or July in 2006 over shoals (Fig. 2).

Annual (for spring-summer) net production of phytoplankton less grazing (Fig. 3) differed substantially by year, depth zone, and size class of phytoplankton and was strongly affected by the assumed value of the efficiency parameter $f$ (Eq. 6). Positive net growth of phytoplankton was possible for small phytoplankton for low values of $f$, particularly in 2006 and over shoals. Large phytoplankton could not achieve positive net production under any value of $f$ in channels, or for values of $f>30 \%$ on shoals in either year (Fig. 3). The two alternative functions for microzooplankton grazing made only a minor difference to the mass balance in all cases.

Components of the phytoplankton mass balance (Eqs. 2-3) show that seasonal gross production was about equal in the two depth zones, but that the greater depth-integrated respiration in the channels led to $\sim$ zero net production there (Fig. 4). In 2006, losses to clam grazing were about equal to combined grazing by the two zooplankton groups, and during summer, clam grazing alone would have been insufficient to prevent phytoplankton from increasing. By contrast, clam grazing in 2007 was greater than zooplankton grazing and exceeded the net growth of phytoplankton. In springs of both years, combined micro- and mesozooplankton grazing was about equal to net phytoplankton growth for large cells. Based on data in Fig. 4, clam grazing made up $51-71 \%$ of seasonal mean total grazing by size class and year, microzooplankton grazing $13-48 \%$, and mesozooplankton 5-24\% (large size fraction only). Because clam and mesozooplankton grazing were size-

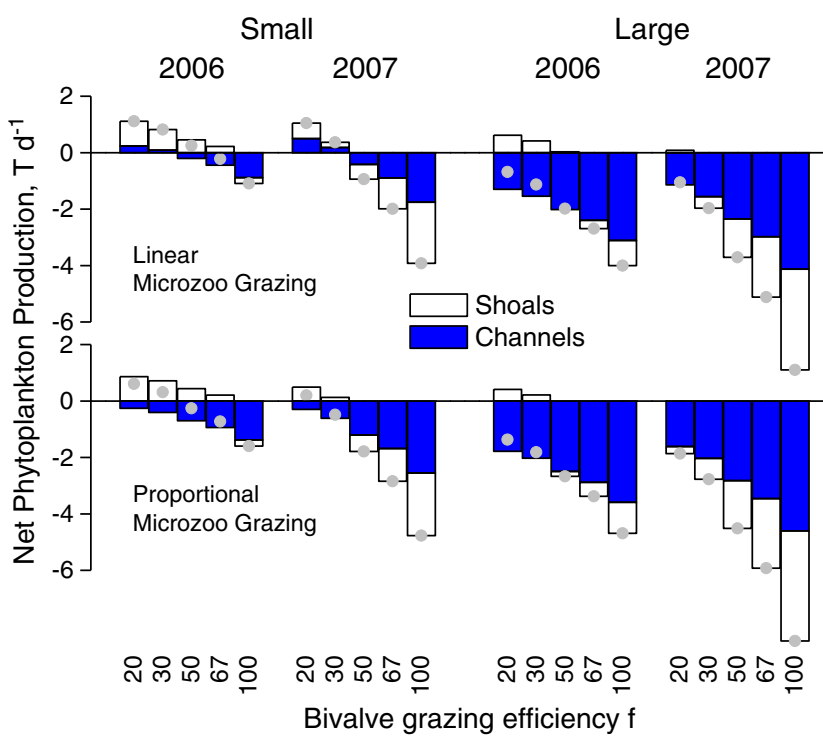

Fig. 3 Estimated mean net production of phytoplankton carbon (tonnes $\left.\mathrm{d}^{-1}\right)$ in 2006 and 2007 for small $(<5 \mu \mathrm{m})$ and large $(>5 \mu \mathrm{m})$ size classes in the low-salinity zone as a function of clam grazing efficiency $(f$, Eq. 6$)$. Top row, microzooplankton grazing from Eq. 5; bottom row, microzooplankton grazing $=60 \%$ of positive phytoplankton growth (Calbet and Landry 2004). Bars show net production or consumption for shoals (open) and channels (filled) in the LSZ for two phytoplankton size fractions, years 2006 and 2007, and five assumed values of $f$. Circles show net production or consumption for the entire LSZ 


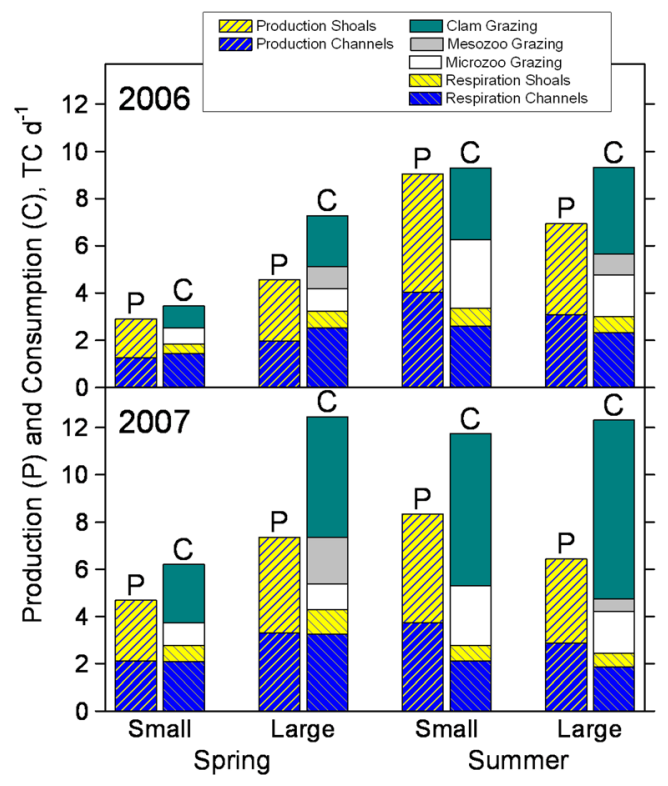

Fig. 4 Balance of phytoplankton production and consumption (tonnes of $\mathrm{C} \mathrm{d}^{-1}$ ) in the low-salinity zone for 2006 (top) and 2007 (bottom). Data shown are means for spring and summer of each year for small $(<5 \mu \mathrm{m})$ and large $(>5 \mu \mathrm{m})$ size classes. The left-hand bar of each pair is production $(P)$ in shoals and channels; the right-hand bar $(C)$ includes respiration in each stratum and total consumption by microzooplankton, mesozooplankton, and clams. Assumptions as in Fig. 2

selective but microzooplankton grazing was assumed not to be, the proportion of total grazing attributable to microzooplankton was higher for the small than for the large size fraction.

Mixing diagrams for chlorophyll taken along transects in July 2008 show clear evidence of a net flux of phytoplankton into the LSZ, as revealed by the concave-upward curve of the relationships of chlorophyll to salinity (Fig. 5). Magnitudes of net flux were somewhat dependent on the precise cutoffs in salinity for including points in the analysis, but signs were consistently negative and confidence limits excluded zero (Fig. 6). Net growth of phytoplankton estimated from three primary production measurements in the LSZ and the spatially intensive clam survey in July 2008 were slightly more negative and with larger confidence intervals (Fig. 6). Taken together, these results confirm a moderate net consumption of phytoplankton in the LSZ during July 2008.

\section{Long-Term Monitoring Data}

The results from analyses using the long-term data from 1987 to 2008 match those of the more intensive studies in 20062007. Phytoplankton growth and clam grazing had similar seasonal patterns with the highest values in summer, although grazing was sometimes high in winter as well (Fig. 7a). Total grazing exceeded net growth almost all of the time (Fig. 7b). Monthly net phytoplankton growth less grazing was positively related to the ratio of chlorophyll in the following month to

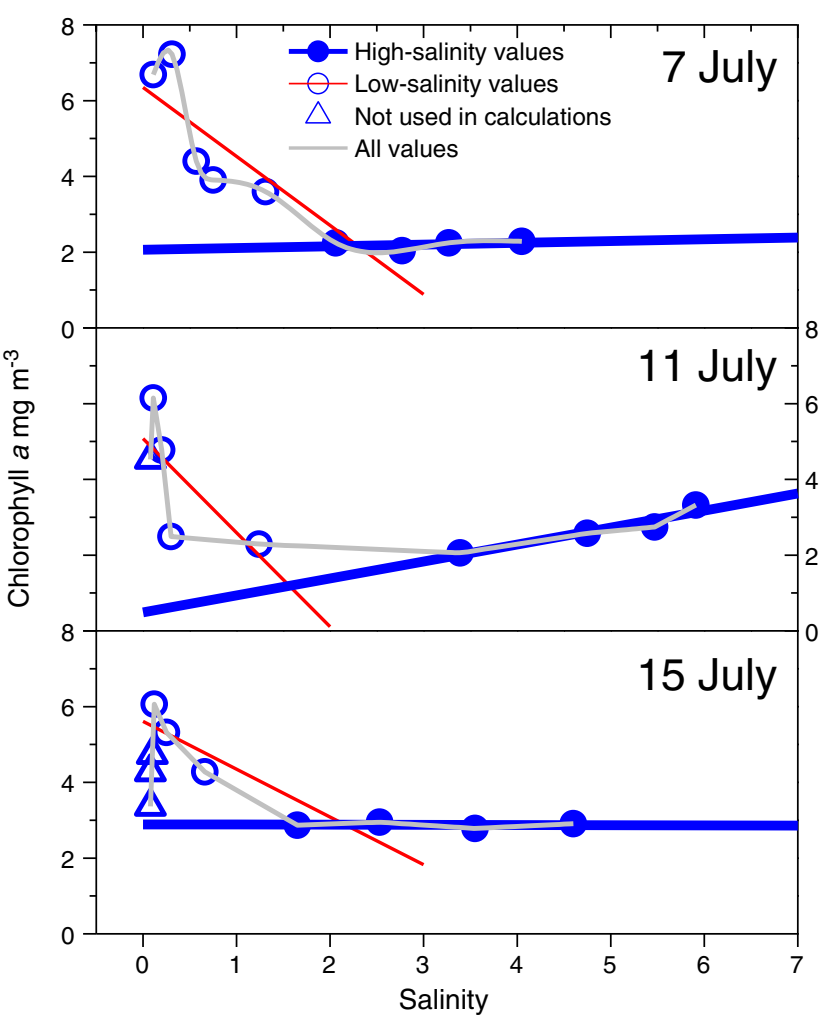

Fig. 5 Mixing diagrams for whole chlorophyll on three transects from the low-salinity zone up the Sacramento River in July 2008

chlorophyll in the current month, indicating consistency between our estimates of net growth rate and biomass accumulation, though with a great deal of scatter (generalized linear model with log link and variance proportional to the mean squared, slope with $95 \%$ CI $0.9 \pm 0.5,228 d f$ ). The only high values of chlorophyll occurred during brief periods in the springs of some years, notably 2000 (Fig. 7c), but chlorophyll was not always high during high-flow springs (Fig. 7d).

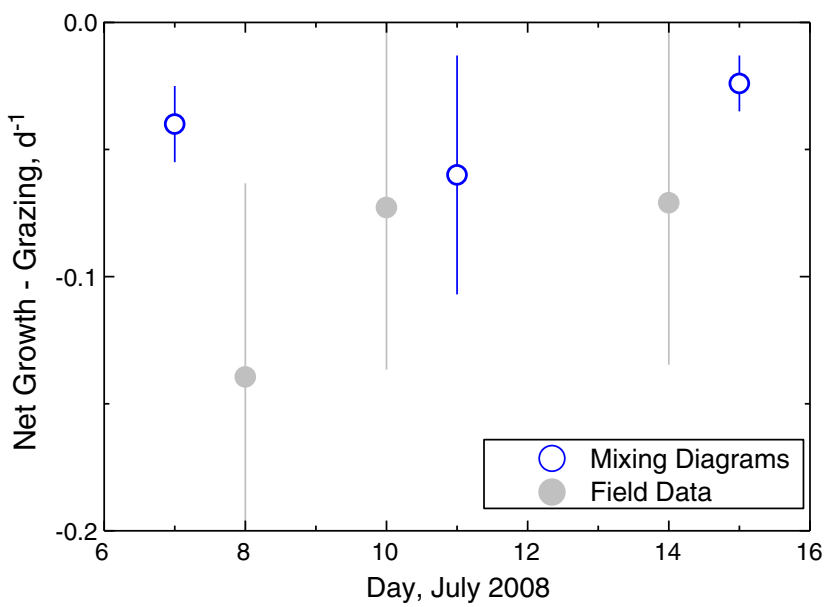

Fig. 6 Net growth rate less grazing rate on phytoplankton biomass estimated from one spatially intensive survey and three productivity measurements in July 2008 and from mixing diagrams shown in Fig. 5. Means and $95 \%$ confidence intervals 


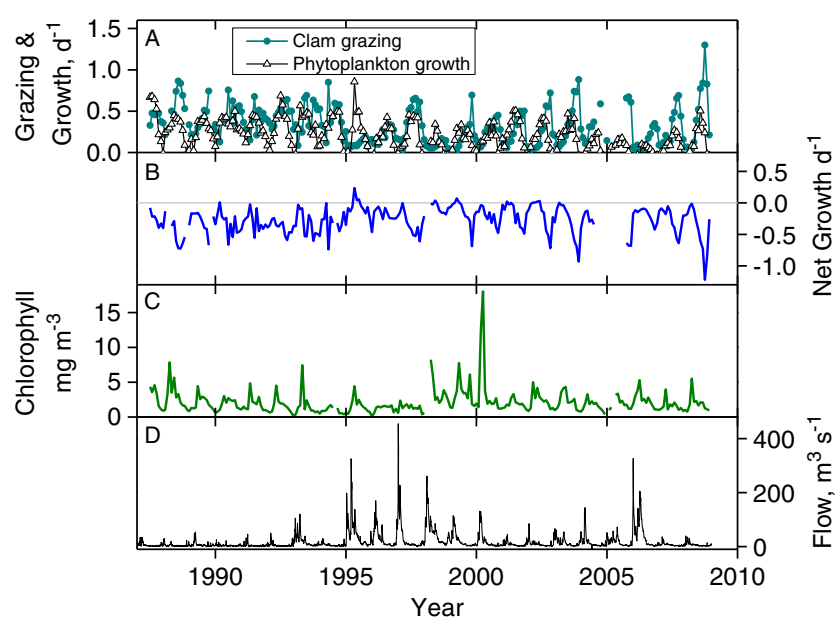

Fig. 7 Phytoplankton production and grazing from long-term monitoring data. a Grazing by clams and phytoplankton net growth. b Net growth rate of whole chlorophyll less grazing by clams, microzooplankton, and mesozooplankton. c Chlorophyll concentration. $D$, Daily freshwater flow into the estuary (net Delta outflow estimate from http://www.water.ca. gov/dayflow/)

Long-term data for the entire period 1971-2010 showed high values of chlorophyll concentration in the LSZ, usually higher than outside the LSZ, in late spring through summer during most years from 1971 to 1986 (Fig. 8). Exceptions occurred during high-flow years (1983) and one extreme drought (1976-1977). In every year from 1987 to 2010, chlorophyll was low during at least some months in the LSZ with a local minimum, usually centered at a salinity around 5 , indicating net consumption of chlorophyll within and seaward

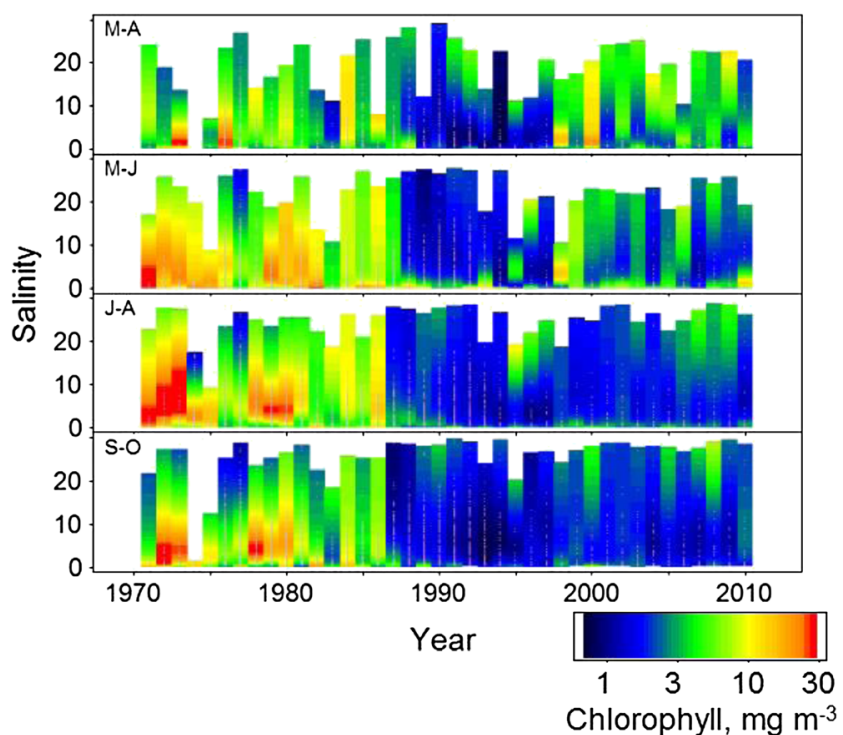

Fig. 8 Image plot of smoothed chlorophyll concentration on a log color scale by year and salinity for four sequential 2-month periods beginning in spring (M-A, March and April). Small gray dots indicate data. Between 26 and 232 data points were included in each bar, with lower counts after 1994 when sampling programs were scaled back. Smoothing was done with salinity (not chlorophyll) on a log scale, which resulted in data gaps at high salinity but emphasized the fresh to low salinity region of the LSZ. This minimum was most pronounced during late summer-early autumn but also occurred in some springs, although blooms occurred in the springs of 1998, 2000, and 2010 (Fig. 8). During most years in 1987-2010 but not from 1971 to 1986 , monthly geometric mean chlorophyll concentration was lower at salinity of $0.5-5$ than at salinity of $0.2-$ 0.5 , also indicating a net flux of phytoplankton biomass from freshwater into the LSZ.

\section{Discussion}

Previous studies of the impact of $P$. amurensis on plankton of the San Francisco Estuary have treated its introduction as a step change. In this paper, we have treated this clam as a naturalized citizen. We examined its ongoing influence on the phytoplankton in a broadened context that includes most of the key controls on phytoplankton biomass: the effect of temporally variable contact between the benthos and plankton, the spatially variable effects of water depth on both phytoplankton growth and benthic grazing, the influence of other grazers, and subsidies of phytoplankton biomass due to mixing and advection. Nutrient concentrations were always high during our study in 2006-2008 (Kimmerer et al. 2012) so we could not address their effects.

Our results show that grazing continues to limit the buildup of phytoplankton biomass. However, in contrast to previous studies emphasizing grazing by bivalves, our results show that bivalve grazing is between $\sim$ half and two thirds of total grazing (Fig. 4). The remainder of the grazing is attributable to microzooplankton and mesozooplankton in roughly equal parts for large phytoplankton and to microzooplankton alone for small phytoplankton, under our assumptions. The monitoring data help to anchor our shorter term results into a longer context, indicating that grazing has suppressed the buildup of phytoplankton biomass for essentially the entire period since P. amurensis was introduced (Fig. 7) and that the contributions to total grazing by the three classes of grazers have been roughly consistent during this period (not shown).

We have refined the calculation of grazing effects through our application of several unique approaches. First, by focusing on a salinity range rather than a particular location, we eliminated the spurious effects of variable salinity, and therefore of planktonic species composition, on our results. To do this required a rather laborious calculation of benthic grazing rates that applied specifically to the LSZ. Second, we included the effects of microzooplankton grazing, which sometimes exceeded bivalve grazing in this study but is often neglected in studies of phytoplankton mass balance (e.g., Jassby et al. 2002; Lopez et al. 2006). Third, we combined spatially intensive surveys with long-term surveys to improve resolution of patterns of benthic grazing over seasonal and interannual time scales (Figs. 2 and 7). Finally, analyses of chlorophyll 
distributions in salinity space were used to bolster confidence in the sign and magnitude of the local mass balance. This outcome is similar to that observed in Willapa Bay (WA, USA), where a mass balance based on exchange with the ocean agreed well with estimates based on grazing by cultivated oysters (Banas et al. 2007).

\section{Controls on Phytoplankton}

Controls on estuarine phytoplankton production have been surprisingly difficult to quantify despite many decades of investigation. Nutrient concentrations, turbidity, and incident light affect phytoplankton growth rate. Growth rate, grazing, advection, and dispersion control the rate of change of biomass. Differences among estuaries in the relative influences of these controlling factors may underlie the high heterogeneity among estuaries in the seasonal patterns of chlorophyll concentration reported by Cloern and Jassby (2010). Resolving the causes of such patterns requires considerable effort to sample both the benthos and the water column at a fine enough spatial and temporal scale and to determine the spatial patterns of linkage between benthos and plankton.

The movement of the salinity gradient can make or break the connection between plankton populations and benthic grazers. Planktonic organisms live in a moving frame of reference and generally remain within a limited range of salinity that moves spatially over tidal to seasonal time scales (Laprise and Dodson 1993). As the gradient moves, the salinity-based planktonic habitat moves into or out of contact with aggregations of benthic grazers, whose distributions vary spatially. Populations of benthic grazers also move with salinity, but by mortality and resettlement. This movement is far slower than the movement of the plankton.

The movement of the salinity gradient also moves plankton in and out of contact with geographic features such as shoals and marshes, deep channels, the estuary mouth, and water intakes and discharges, all of which can influence phytoplankton population growth and species composition. Mean depth affects the depth of the euphotic zone and proportional losses to benthic grazers. Stratification, which is more frequent in deep channels with a strong longitudinal salinity gradient, can stimulate blooms in the surface layer (Lucas et al. 1999). Gravitational circulation, which occurs when the water column is stratified, can retain and concentrate sinking plankton and particles in a turbidity maximum. Oceanic phytoplankton entering through the mouth can contribute substantially to biomass within the estuary (Kimmerer et al. 2012).

Most studies of the impact of bivalves on phytoplankton in natural waters are from situations in which depletion of biomass by grazing can be readily separated from other effects in time or space. These include studies of invasions (Strayer 2009) or declines in bivalve abundance (Phelps 1994), comparisons among lakes with and without bivalves (MacIsaac
1996), and analyses of changes in biomass with distance using a space-for-time substitution (Caraco et al. 1997). Such studies almost invariably have shown bivalve grazing to be a key factor in limiting the accumulation of phytoplankton biomass.

Often, however, the effects of grazing cannot be readily separated from other effects and are complicated by tidal mixing. In these cases, inferences must be made using mass balance based on extrapolation from the laboratory (Alpine and Cloern 1992) or localized field experiments (Jones et al. 2009). In these situations, it is essential not only to quantify benthic grazing over a region in which the grazing impact is to be estimated, but also to quantify losses to pelagic grazers. This requires analyses of primary production along with grazing by micro- and mesozooplankton and the benthos (Eqs. 13 ). Few published analyses include all three groups of grazers.

This study demonstrates that the combined grazing by zooplankton and bivalves controls the accumulation of phytoplankton biomass in the upper SFE. This was clearly the case during the years of our field study (2006-2008), and the long-term data suggest that production of phytoplankton in the low-salinity zone has exceeded consumption only infrequently. These results agree broadly with those of earlier analyses in which time series of phytoplankton biomass and production (Alpine and Cloern 1992; Kimmerer 2005) and abundance of higher trophic levels (Orsi and Mecum 1996; Kimmerer 2006; Thomson et al. 2010) were correlated with a step change at the time $P$. amurensis spread through the estuary. Our analysis is not a corroboration of those earlier results, but an extension of our understanding of bivalve grazing into a broader context of limits on growth of the phytoplankton, other grazing, and the movement of water.

Our results show that, in the LSZ of the San Francisco Estuary, phytoplankton could sometimes grow fast enough to overcome bivalve grazing alone, but rarely could phytoplankton escape all grazing. Microzooplankton grazing in particular was an important loss term, as has been reported from other studies (Calbet and Landry 2004), although our results rest on the assumption of linear relationships between phytoplankton growth and microzooplankton grazing observed in this study (York et al. 2011) and elsewhere (Calbet and Landry 2004). Grazing by mesozooplankton overall was the smallest grazing loss for phytoplankton, although not negligible, and it may have been underestimated if the gross growth efficiency of copepods was lower than the value we used (discussed below).

Controls on phytoplankton biomass accumulation were very different over shoals than in channels, as previously reported for other parts of the estuary (Lucas et al. 1999; Lopez et al. 2006). The phytoplankton mass balance was neutral to slightly positive over shoals in 2006 and strongly negative in channels in 2006 and in both regions in 2007 (Figs. 2 and 3). Gross areal production was about the same over shoals as in channels since the $1 \%$ light level was only $\sim 1.2 \mathrm{~m}$ deep even in the channels 
(Kimmerer et al. 2012). Estimated respiratory and planktonic grazing losses per unit volume were similar in shoals and channels, but values integrated through the water column were greater in channels. In contrast, the daily fraction of the water column filtered by clams scales inversely with water depth such that the same filtration rate $G_{\mathrm{c}}$ (Eq. 3) results in much faster loss in shoals than channels. During 2006-2007, clams were generally larger in deep than in shallow water, which somewhat offset the effect of depth on loss rate of phytoplankton to benthic grazing.

Grazing produced a negative local mass balance of phytoplankton biomass most of the time, especially in late summer and into autumn (Fig. 7). The brief and usually small spikes in chlorophyll in spring in the LSZ (Fig. 7c) sometimes occurred during high-flow periods when plankton and peak biomass of clams may have become spatially separated, reducing the effects of benthic grazing on the plankton, or when stratification may have stimulated blooms. Alternatively, these spikes may have arisen through advection, since the broad scale data over the same years (Fig. 8) do not show spring blooms in the LSZ during most years post-Potamocorbula.

The depletion of chlorophyll in the LSZ in summers and some springs since 1987 could usually, but not always, be attributed to seasonal and interannual patterns of clam abundance. This depletion was particularly strong from summer 1987 until 1995, the first very wet year after the clam invasion and the first year in which the local mass balance of phytoplankton biomass was slightly positive for several consecutive months (Fig. 7b). Over the next decade, a slightly positive local mass balance recurred several times, usually in winterspring when clam abundance was low in Suisun Bay. The mass balance was consistently negative during 2003-2008 (data are missing for part of 2005), which is consistent with the lower chlorophyll concentration in the LSZ during summer-autumn after 2003 (Fig. 8). These patterns are at least partly due to the extent of winter-spring survival of large clams, which have correspondingly high grazing rates (Thompson 2005). During 1988-1994, large clams were fairly numerous in spring (based on size distributions, not shown), but during wet winters in 1995-2006, over-wintering clams died off and grazing rates were low in the following spring until new recruits grew large enough to establish a high grazing rate.

In contrast to the influence of clams in most years, clam grazing was low in the very wet spring of 2006 yet no bloom occurred (Fig. 2, Kimmerer et al. 2012). Apparently, high cloud cover limited sunlight and therefore phytoplankton growth rate. This demonstrates the need to consider variability in all terms of a mass balance to understand the patterns of variability in the phytoplankton.

The factors affecting phytoplankton biomass throughout the San Francisco Estuary have distinct temporal and spatial patterns (Cloern and Jassby 2012). The low salinity region of the estuary, however, remains a high-nutrient, low-chlorophyll region as a result of high turbidity (Cloern and Jassby 2012; Kimmerer et al. 2012) and grazing (Alpine and Cloern 1992; this paper). In addition, only about half of the productivity in the LSZ in 2006-2007 was in cells larger than $5 \mu \mathrm{m}$, probably because of more efficient grazing by clams and mesozooplankton on these larger particles (Werner and Hollibaugh 1993; Figs. 2, 3, and 4, Table 1). The small mean size of the phytoplankton leads to a foodweb in which the numerically dominant copepods feed mainly on ciliates (Bouley and Kimmerer 2006; York et al. 2013), resulting in an extra trophic level and an inefficient transfer of energy to higher order consumers such as fish.

High ammonium concentrations may suppress growth rate of diatoms and therefore biomass accumulation in the upper estuary (Wilkerson et al. 2006). Low ammonium could therefore contribute to the occasional spring blooms (Fig. 8 and Dugdale et al. 2007-Fig. 1a). However, for most of the springs-summers in the data record, grazing was sufficient to consume phytoplankton faster than they could grow (Fig. 7). High phytoplankton biomass in most summers before 1987 was attributed to accumulation of biomass in the absence of much grazing rather than high growth rate, which was actually lower than growth rate in spring (Cole and Cloern 1984; Nichols 1985). Light-saturated 24-h phytoplankton growth rates $\mathrm{P}^{\mathrm{B}}{ }_{\mathrm{M}(24)}$ were lower in spring 2006, about equal in summer 2006, and higher in spring-summer 2007, compared to the same seasons in 1980, while ammonium concentrations were substantially higher in 2006-2007 than in 1980 (Parker et al. 2012). Thus, while high ammonium may have measurable and possibly important effects on phytoplankton production in some parts of the estuary, there is no direct evidence of such effects within the LSZ based on these years in which primary production was measured.

In some systems, bivalves play an important role in nutrient regeneration and redistribution (Prins et al. 1998; Nielsen and Maar 2007). However, nutrient concentrations in the upper SFE are chronically high: the mean ammonium concentration measured in this study during 2006-2007 was 4.5 $\mu_{\mathrm{mol}}{ }^{-1}$, and nitrate averaged $16 \mu \mathrm{mol} \mathrm{l}^{-1}$ in 2006 and $32 \mu \mathrm{mol}{ }^{-1}$ in 2007 (Kimmerer et al. 2012). Experimentally determined excretion rates of $P$. amurensis from Suisun Bay averaged $\sim 5.0 \mu \mathrm{mol} \mathrm{NH} 4 \mathrm{~h}^{-1}$ (g AFDW) $^{-1}$ (Kleckner 2009). Using our biomass estimates for both clam species and a mean depth of $5 \mathrm{~m}$, excretion of clams provided $\sim 2 \% \mathrm{~d}^{-1}$ (median) of the water column stock of ammonium. Uptake by phytoplankton based on primary production measurements (Kimmerer et al. 2012) and assuming Redfield stoichiometry (molar $\mathrm{C} / \mathrm{N}$ of 6.6 ) averaged $\sim 6 \%$ of the ammonium stock. Thus, dissolved inorganic nitrogen concentrations in the LSZ during the study period were likely under the control of external inputs and excretion by clams was unlikely to materially affect phytoplankton uptake rates. 
Reliability of the Results

Our approach included measurements of all of the components of Eqs. 1-4, although at various frequencies and levels of resolution. Uncertainty in the assumptions underlying our approach and the wide confidence limits in the components of the analysis lead to considerable uncertainty even in the sign of the estimated local mass balance (Figs. 2 and 3). Independent analyses of phytoplankton flux $\Phi$ from the mixing diagrams were therefore helpful in corroborating our estimates.

Extrapolating laboratory-derived benthic grazing rates to the field involves a leap of faith, although it is the most common method for estimating field grazing rate. Various factors may cause field grazing rates to differ from those in the laboratory, including intermittency of filtering by grazers due to currents and other environmental conditions, different sizes or other characteristics of phytoplankton, selective feeding, interference by suspended sediments, and depletion of the benthic boundary layer. We have dealt explicitly with boundary layer depletion by using results from laboratory experiments using artificial clam beds (O'Riordan et al. 1995). Intermittency of filtration was detected in field experiments, providing us with the estimate that clams filter $\sim 67 \%$ of the time (Thompson 1999). However, that proportion is almost certainly variable, and we have not addressed other environmental influences on grazing except for phytoplankton size.

Three pieces of information support the accuracy of our extrapolation of grazing rates from the laboratory. The first is the sag in chlorophyll concentration in the LSZ (Figs. 5 and 8), indicating net consumption within the LSZ (Eq. 1) and corroborating our calculations based on mass balance. The second is a finding that grazing estimated by extrapolation of the same laboratory rates actually underestimated depletion of chlorophyll within a carefully delineated control volume in a shallow channel in Suisun Marsh linked to northern Suisun Bay (Jones et al. 2009). The excessive depletion was apparently caused by a flocculent layer supported by organic matter from the marsh, which is unlikely to be of much importance in the more energetic, less organic-rich open waters of the estuary. The third is the general agreement between laboratoryderived estimates of grazing rate and those based on independent field measurements in other studies (e.g., Caraco et al. 1997; Banas et al. 2007).

The most reliable quantities in Eq. 1 are the primary production estimates, which rest on numerous measurements, and there is relatively little variability among dates or salinity values (Fig. 2; Kimmerer et al. 2012). Carbon biomass used in estimates of respiration were determined by microscopic counts (Lidström 2009) in 2006-2007 and from chlorophyll in 2008 and in the long-term data sets. The carbon-tochlorophyll ratio used for that conversion was determined from 40 measurements in 2007, which gave a mean ratio of
25, lower than previous estimates (Cloern et al. 1995, Kimmerer et al. 2012). These low $\mathrm{C} / \mathrm{Chl}$ ratios determined in our study suggest that the biomass from counts may be underestimated, possibly because of difficulties in counting small cells in the high-particulate water, although the low values are consistent with the primary production measurements (Parker et al. 2012). If the $\mathrm{C} / \mathrm{Chl}$ ratio is actually higher than this value, then we have underestimated phytoplankton respiration and the actual local mass balance is more negative than shown in Fig. 7.

Microzooplankton grazing rates are not constrained well by the measurements from our study (York et al. 2011). However, using an alternative estimate of the relationship between microzooplankton grazing and phytoplankton growth based on published reports from estuaries (Calbet and Landry 2004) yielded little difference in the estimates of microzooplankton growth (Table 2, Fig. 3).

Individual estimates of grazing rate of the mesozooplankton have several sources of uncertainty, including the small number of measurements of growth, the assumption that all feeding was on particles $>5 \mu \mathrm{m}$, and use of the literature-based gross growth efficiency. The $5-\mu \mathrm{m}$ cutoff for feeding is approximate and based on a wide variety of feeding studies. We selected a gross growth efficiency of $30 \%$, typical for copepods growing under low-food conditions (Straile 1997; Calliari et al. 2006; Almeda et al. 2012). A reasonable lower value of $20 \%$ would have resulted in a $50 \%$ higher grazing rate by mesozooplankton on large cells, making the grazing rate more closely comparable to that of microzooplankton. However, the calculations based on the mixing diagrams suggest that the net loss rate of phytoplankton is probably not more than that estimated from the grazing calculations, at least during 2008.

During spring of 2006, the LSZ and therefore the water column sampling sites were not in Suisun Bay where the spatially extensive benthic samples were taken in March. Estimates from a single shallow station in San Pablo Bay were similar to those from Suisun Bay, justifying our use of the Suisun Bay rates. However, two other confounding factors affected phytoplankton bloom development during spring 2006: the water column was stratified, probably reducing the effects of turbidity and clam grazing on phytoplankton, and cloudy weather limited phytoplankton growth rates (Kimmerer et al. 2012). We have no way to correct for the effects of stratification.

\section{Implications}

Can grazing truly be said to control the accumulation of phytoplankton biomass, in the sense of a feedback mechanism (Prins et al. 1998)? Microzooplankton grazing is generally modeled as a proportion or a linear covariate of phytoplankton growth rate (Calbet and Landry 2004), presumably because 
microzooplankton can grow quickly enough to keep up with phytoplankton growth. This implies a feedback mechanism from increased phytoplankton growth through increased biomass to numerical response of microzooplankton and consequently increased grazing.

Phytoplankton and bivalve biomass could covary as a result of food limitation of clam growth (time scale of weeks to months) or from behavioral responses of clams to changing food supply (shorter time scale), assuming that most of the clam food is phytoplankton. Food limitation in bivalves has been reported for C. fluminea and Macoma balthica in the SFE (Foe and Knight 1986; Thompson and Nichols 1988) and is probably common. Reproduction by $P$. amurensis is keyed to food supply (Nicolini and Penry 2000; Parchaso and Thompson 2002). Rapid growth of P. amurensis in early spring of 1995 led to grazing pressure high enough to stop the spring phytoplankton bloom in south San Francisco Bay (Thompson et al. 2008). Thus, a response of bivalves to increasing phytoplankton biomass through growth or through reproduction and settlement seems likely but unless there is a sustained higher chlorophyll level, it is unlikely that we would see a bivalve response at the temporal scale of the sampling. Although, we were unable to detect evidence of a quantitative response of bivalve biomass to chlorophyll concentration in our study, bivalve biomass consistently increased through summer into fall of most years (Figs. 2 and 7a).

Behavioral responses are less certain, and our benthic grazing estimates were based on laboratory experiments that do not account for any behavioral response of clams to an increase in the food supply. As phytoplankton biomass increases in spring, bivalves may increase their filtration frequencies or rates, which would result in an accelerating (type III, Holling 1959) functional response. This would be an important feedback mechanism, but as far as we know, it has not been investigated.

Several fish species in the San Francisco Estuary declined sharply in 2002 (Sommer et al. 2007). Although these declines have not been statistically linked to declines in phytoplankton (Thomson et al. 2010), a probable contributing factor to low fish abundance is the continued low productivity of the LSZ foodweb. Low primary productivity is clearly attributable to the combination of high turbidity and high grazing rate by zooplankton and clams, particularly $P$. amurensis. The putative contributions of nutrient concentrations or ratios in the low productivity of this region (Dugdale et al. 2007, Glibert et al. 2011) appear negligible compared to the large, direct effects of grazing.

Low production by mesozooplankton (Gould and Kimmerer 2010) is a function of low productivity and small size of the phytoplankton (Kimmerer et al. 2012). Low phytoplankton productivity was principally a result of high grazing rates and strongly light-limited phytoplankton growth rates. Size-selective grazing by clams, and to a much lesser extent mesozooplankton, suppressed the larger phytoplankton cells more than the smaller ones, reducing the availability of food for mesozooplankton. The resulting paucity of mesozooplankton is very likely a limiting factor to recovery of the declining fish species (Sommer et al. 2007).

The state of California is planning a substantial investment in restoration of marshes and shoals to provide physical habitat and to enhance production of planktonic food for the endangered delta smelt and other pelagic fishes (http:// baydeltaconservationplan.com/). If the accumulation of phytoplankton biomass is controlled principally by grazing, as our results indicate, such restoration may have little influence on the pelagic foodweb and the recovery of these fishes (Lopez et al. 2006).

Acknowledgments We thank F. Parchaso, M. Shouse, H. Peterson, A. Kleckner, A. Gould, V. Greene, U. Lidström, T. Ignoffo, and A. Slaughter for assistance in the field and the laboratory and D. Bell and D. Morgan for vessel and logistic support. J. York provided help in the field and the data for microzooplankton grazing rates. Thanks to K. Gehrts and D. Messer of the California Department of Water Resources for giving us access to EMP benthic samples. M. Weaver, D. Strayer, and L. Brown provided helpful comments on earlier versions of the manuscript. Funding was provided by the CALFED Bay-Delta Science Program under grant SCI-05-C107 and by the U.S Geological Survey PES/ TOXICS/NRP Programs.

Open Access This article is distributed under the terms of the Creative Commons Attribution License which permits any use, distribution, and reproduction in any medium, provided the original author(s) and the source are credited.

\section{References}

Almeda, R., C.B. Augustin, M. Alcaraz, A. Calbet, and E. Saiz. 2012. Feeding rates and gross growth efficiencies of larval developmental stages of Oithona davisae (Copepoda, Cyclopoida). Journal of Experimental Marine Biology and Ecology 387: 24-35.

Alpine, A.E., and J.E. Cloern. 1992. Trophic interactions and direct physical effects control phytoplankton biomass and production in an estuary. Limnology and Oceanography 37: 946-955.

Banas, N.S., B.M. Hickey, J.A. Newton, and J.L. Ruesink. 2007. Tidal exchange, bivalve grazing, and patterns of primary production in Willapa Bay, Washington, USA. Marine Ecology Progress Series 341: 123-139.

Beukema, J.J., and G.C. Cadee. 1996. Consequences of the sudden removal of nearly all mussels and cockles from the Dutch Wadden sea. Marine Ecology-Pubblicazioni Della Stazione Zoologica Di Napoli I 17: 279-289.

Bouley, P., and W.J. Kimmerer. 2006. Ecology of a highly abundant, introduced cyclopoid copepod in a temperate estuary. Marine Ecology Progress Series 324: 219-228.

Calbet, A., and M.R. Landry. 2004. Phytoplankton growth, microzooplankton grazing, and carbon cycling in marine systems. Limnology and Oceanography 49: 51-57.

Calliari, D., C.M. Andersen, P. Thor, E. Gorokhova, and P. Tiselius. 2006. Salinity modulates the energy balance and reproductive success of co-occurring copepods Acartia tonsa and A. clausi in different ways. Marine Ecology Progress Series 312: 177-188. 
Caraco, N.F., J.J. Cole, P.A. Raymond, D.L. Strayer, M.L. Pace, S.E.G. Findlay, and D.T. Fischer. 1997. Zebra mussel invasion in a large, turbid river: phytoplankton response to increased grazing. Ecology 78: 588-602.

Caraco, N.F., J.J. Cole, and D.L. Strayer. 2006. Top-down control from the bottom: regulation of eutrophication in a large river by benthic grazing. Limnology and Oceanography 51: 664-670.

Cloern, J.E. 1982. Does the benthos control phytoplankton biomass in south San Francisco Bay (USA)? Marine Ecology Progress Series 9: 191-202.

Cloern, J.E., and A.D. Jassby. 2010. Patterns and scales of phytoplankton variability in estuarine-coastal ecosystems. Estuaries and Coasts 33: 230-241.

Cloern, J.E., and A. Jassby. 2012. Drivers of change in estuarine-coastal ecosystems: discoveries from four decades of study in San Francisco Bay. Reviews in Geophysics 50.

Cloern, J.E., C. Grenz, and L. Vidergar-Lucas. 1995. An empirical model of the phytoplankton chlorophyll/carbon ratio- the conversion factor between productivity and growth rate. Limnology and Oceanography 40: 1313-1321.

Cloern, J.E., A.D. Jassby, J.K. Thompson, and K.A. Hieb. 2007. A cold phase of the East Pacific triggers new phytoplankton blooms in San Francisco Bay. Proceedings of the National Academy of Sciences, USA 104: 18561-18565

Cole, B.E., and J.E. Cloern. 1984. Significance of biomass and light availability to phytoplankton productivity in San Francisco Bay. Marine Ecology Progress Series 17: 15-24.

Cole, B.E., J.K. Thompson, and J.E. Cloern. 1992. Measurement of filtration rates by infaunal bivalves in a recirculating flume. Marine Biology 113: 219-225.

Cordell, J.R., S.M. Bollens, R. Draheim, and M. Sytsma. 2008. Asian copepods on the move: recent invasions in the Columbia-Snake River system, USA. ICES Journal of Marine Science 65: 753758 .

Culberson, S. D., C. B. Harrison, C. Enright, and M. L. Nobriga. 2004. Sensitivity of larval fish transport to location, timing, and behavior using a particle tracking model in Suisun Marsh, California. Early life history of fishes in the San Francisco Estuary and Watershed, eds. F. Feyrer, L. R. Brown, R. L. Brown and J. J. Orsi, 257-267: American Fisheries Society Symposium Vol. 39. Bethesda MD: American Fisheries Society.

Daskalov, G.M., A.N. Grishin, S. Rodionov, and V. Mihneva. 2007. Trophic cascades triggered by overfishing reveal possible mechanisms of ecosystem regime shifts. Proceedings of the National Academy of Sciences, USA 104: 10518-10523.

Dugdale, R.C., F.P. Wilkerson, V.E. Hogue, and A. Marchi. 2007. The role of ammonium and nitrate in spring bloom development in San Francisco Bay. Estuarine, Coastal and Shelf Science 73: $17-29$.

Fishman, D.B., S.A. Adlerstein, H.A. Vanderploeg, G.L. Fahnenstiel, and D. Scavia. 2009. Causes of phytoplankton changes in Saginaw Bay, Lake Huron, during the zebra mussel invasion. Journal of Great Lakes Research 35: 482-495.

Foe, C., and A. Knight. 1986. A thermal energy budget for juvenile Corbicula fluminea, International Corbicula Symposium. Little Rock: American Malacological Bulletin.

Glibert, P.M., D. Fullerton, J.M. Burkholder, J.C. Cornwell, and T.M. Kana. 2011. Ecological stoichiometry, biogeochemical cycling, invasive species, and aquatic food webs: San Francisco Estuary and comparative systems. Reviews in Fisheries Science 19: 358-417.

Gorokhova, E., S. Hansson, H. Hoglander, and C.M. Andersen. 2005. Stable isotopes show food web changes after invasion by the predatory cladoceran Cercopagis pengoi in a Baltic Sea bay. Oecologia 143: 251-259.

Gould, A.L., and W.J. Kimmerer. 2010. Development, growth, and reproduction of the cyclopoid copepod Limnoithona tetraspina in the upper San Francisco Estuary. Marine Ecology Progress Series 412: $163-177$.

Greene, V.E., L.J. Sullivan, J.K. Thompson, and W.J. Kimmerer. 2011. Grazing impact of the invasive clam Corbula amurensis on the microplankton assemblage of the northern San Francisco Estuary. Marine Ecology Progress Series 431: 183-193.

Hastie, T.J., and R.J. Tibshirani. 1990. Generalized additive models. London: Chapman and Hall.

Holling, C.S. 1959. The components of predation as revealed by a study of small mammal predation of the European Pine Sawfly. Canadian Entomologist 91: 293-320.

Huber, M. 2010. Potamocorbula amurensis (Schrenck, 1861). In World Marine Mollusca database, eds. P. Bouchet, S. Gofas, and G. Rosenberg. Accessed on 2012-07-19 through World Register of Marine Species at http://www.marinespecies.org/aphia.php? $\mathrm{p}=$ taxdetails\&id $=397175$

Jassby, A. D. 2008. Phytoplankton in the upper San Francisco Estuary: recent biomass trends, their causes and their trophic significance. San Francisco Estuary and Watershed Science 6: Issue 1 Article 2.

Jassby, A.D., W.J. Kimmerer, S.G. Monismith, C. Armor, J.E. Cloern, T.M. Powell, J.R. Schubel, and T.J. Vendlinski. 1995. Isohaline position as a habitat indicator for estuarine populations. Ecological Applications 5: 272-289.

Jassby, A.D., J.E. Cloern, and B.E. Cole. 2002. Annual primary production: patterns and mechanisms of change in a nutrient-rich tidal estuary. Limnology and Oceanography 47: 698-712.

Jones, N.L., J.K. Thompson, K.R. Arrigo, and S.G. Monismith. 2009. Hydrodynamic control of phytoplankton loss to the benthos in an estuarine environment. Limnology and Oceanography 54: 952-969.

Jorgensen, C.B., and K. Ockelmann. 1991. Beat frequency of lateral cilia in intact filter feeding bivalves - effect of temperature. Ophelia 33: $67-70$.

Kimmerer, W.J. 2005. Long-term changes in apparent uptake of silica in the San Francisco Estuary. Limnology and Oceanography 50: 793-798.

Kimmerer, W.J. 2006. Response of anchovies dampens effects of the invasive bivalve Corbula amurensis on the San Francisco Estuary foodweb. Marine Ecology Progress Series 324: 207-218.

Kimmerer, W.J., W.A. Bennett, and J.R. Burau. 2002. Persistence of tidally-oriented vertical migration by zooplankton in a temperate estuary. Estuaries 25: 359-371.

Kimmerer, W.J., A.E. Parker, U. Lidström, and E.J. Carpenter. 2012. Short-term and interannual variability in primary production in the low-salinity zone of the San Francisco Estuary. Estuaries and Coasts 35: 913-929.

Kimmerer, W.J., T.R. Ignoffo, A.M. Slaughter, and A. L. Gould. 2013 Food-limited reproduction and growth of three copepod species in the low-salinity zone of the San Francisco Estuary. Journal of Plankton Research (in press).

Kleckner, A. E. 2009. The role of an invasive bivalve, Corbula amurensis, in the cycling of nitrogen in Suisun Bay, CA. MS Thesis: San Francisco State University.

Laprise, R., and J.J. Dodson. 1993. Nature of environmental variability experienced by benthic and pelagic animals in the St. Lawrence Estuary, Canada. Marine Ecology Progress Series 94: 129-139.

Larsen, P.S., and H.U. Riisgard. 2009. Viscosity and not biological mechanisms often controls the effects of temperature on ciliary activity and swimming velocity of small aquatic organisms. Journal of Experimental Marine Biology and Ecology 381: 67-73.

Lidström, U. E. 2009. Primary production, biomass and species composition of phytoplankton in the low salinity zone of the northern San Francisco Estuary. MS Thesis, San Francisco State University.

Lonsdale, D.J., R.M. Cerrato, R. Holland, A. Mass, L. Holt, R.A. Schaffner, J. Pan, and D.A. Caron. 2009. Influence of suspensionfeeding bivalves on the pelagic food webs of shallow, coastal embayments. Aquatic Biology 6: 263-279. 
Lopez, C.B., J.E. Cloern, T.S. Schraga, A.J. Little, L.V. Lucas, J.K. Thompson, and J.R. Burau. 2006. Ecological values of shallowwater habitats: implications for the restoration of disturbed ecosystems. Ecosystems 9: 422-440.

Lucas, L.V., J.E. Cloern, J.R. Koseff, S.G. Monismith, and J.K. Thompson. 1998. Does the Sverdrup critical depth model explain bloom dynamics in estuaries? Journal of Marine Research 56: $375-415$.

Lucas, L.V., J.R. Koseff, S.G. Monismith, J.E. Cloern, and J.K. Thompson. 1999. Processes governing phytoplankton blooms in estuaries. II: The role of horizontal transport. Marine Ecology Progress Series 187: 17-30.

MacIsaac, H.J. 1996. Potential abiotic and biotic impacts of zebra mussels on the inland waters of North America. American Zoologist 36: 287-299.

Nichols, F.H. 1985. Increased benthic grazing: an alternative explanation for low phytoplankton biomass in northern San Francisco Bay during the 1976-1977 drought. Estuarine, Coastal and Shelf Science 21: 379-388.

Nicolini, M.H., and D.L. Penry. 2000. Spawning, fertilization, and larval development of Potamocorbula amurensis (Mollusca: Bivalvia) from San Francisco Bay, California. Pacific Science 54: 377388.

Nielsen, T.G., and M. Maar. 2007. Effects of a blue mussel Mytilus edulis bed on vertical distribution and composition of the pelagic food web. Marine Ecology Progress Series 339: 185-198.

Officer, C.B., and D.R. Lynch. 1981. Dynamics of mixing in estuaries. Estuarine, Coastal and Shelf Science 12: 525-533.

O'Riordan, C.A., S.G. Monismith, and J.R. Koseff. 1995. The effect of bivalve excurrent jet dynamics on mass transfer in a benthic boundary layer. Limnology and Oceanography 40: 330-344.

Orsi, J., and W. Mecum. 1986. Zooplankton distribution and abundance in the Sacramento-San Joaquin Delta in relation to certain environmental factors. Estuaries 9: 326-339.

Orsi, J.J., and W.L. Mecum. 1996. Food limitation as the probable cause of a long-term decline in the abundance of Neomysis mercedis the opossum shrimp in the Sacramento-San Joaquin Estuary. In San Francisco Bay: the ecosystem, ed. J.T. Hollibaugh, 375-401. San Francisco: AAAS.

Pace, M.L., S.E.G. Findlay, and D. Fischer. 1998. Effects of an invasive bivalve on the zooplankton community of the Hudson River. Freshwater Biology 39: 103-116.

Parchaso, F., and J.K. Thompson. 2002. Influence of hydrologic processes on reproduction of the introduced bivalve Potamocorbula amurensis in Northern San Francisco Bay, California. Pacific Science 56: 329-346.

Parker, A., W. Kimmerer, and U. Lidström. 2012. Reevaluating the generality of an empirical model for light-limited primary production in the San Francisco Estuary. Estuaries and Coasts 35: 930942.

Peterson, H. A., and M. Vayssières. 2010. Benthic assemblage variability in the upper San Francisco Estuary: a 27-year retrospective. San Francisco Estuary and Watershed Science 8: [np].
Phelps, H.L. 1994. The Asiatic clam (Corbicula fluminea) invasion and system-level ecological change in the Potomac River Estuary near Washington, D.C. Estuaries 17: 614-621.

Prins, T.C., A.C. Smaal, and R.F. Dame. 1998. A review of the feedbacks between bivalve grazing and ecosystem processes. Aquatic Ecology 31: 349-359.

Schoellhamer, D.H. 2011. Sudden clearing of estuarine waters upon crossing the threshold from transport to supply regulation of sediment transport as an erodible sediment pool is depleted: San Francisco Bay, 1999. Estuaries and Coasts 34: 885-899.

Sommer, T., C. Armor, R. Baxter, R. Breuer, L. Brown, M. Chotkowski, S. Culberson, F. Feyrer, M. Gingras, B. Herbold, W. Kimmerer, A. Mueller Solger, M. Nobriga, and K. Souza. 2007. The collapse of pelagic fishes in the upper San Francisco Estuary. Fisheries 32: 270-277.

Straile, D. 1997. Gross growth efficiencies of protozoan and metazoan zooplankton and their dependence on food concentration, predatorprey weight ratio, and taxonomic group. Limnology and Oceanography 42: 1375-1385.

Strayer, D.L. 2009. Twenty years of zebra mussels: lessons from the mollusk that made headlines. Frontiers in Ecology and the Environment 7: 135-141.

Thompson, J. K. 1999. The effect of infaunal bivalve grazing on phytoplankton bloom development in South San Francisco Bay. Ph.D. thesis. Stanford University.

Thompson, J. K. 2005. One estuary, one invasion, two responses: phytoplankton and benthic community dynamics determine the effect of an estuarine invasive suspension-feeder. Comparative Roles of Suspension-Feeders in Ecosystems, 291-316: NATO Science Series IV Earth and Environmental Sciences : 47.

Thompson, J.K., and F.H. Nichols. 1988. Food availability controls seasonal cycle of growth in Macoma balthica (L.) in San Francisco Bay, California. Journal of Experimental Marine Biology and Ecology 116: 43-61.

Thompson, J.K., J.R. Koseff, S.G. Monismith, and L.V. Lucas. 2008. Shallow water processes govern system-wide phytoplankton bloom dynamics: a field study. Journal of Marine Systems 74: 153-166.

Thomson, J., W. Kimmerer, L. Brown, K. Newman, R. Mac Nally, W. Bennett, F. Feyrer, and E. Fleishman. 2010. Bayesian change-point analysis of abundance trends for pelagic fishes in the upper San Francisco Estuary. Ecological Applications 20: 1431-1448.

Werner, I., and J.T. Hollibaugh. 1993. Potamocorbula amurensis - comparison of clearance rates and assimilation efficiencies for phytoplankton and bacterioplankton. Limnology and Oceanography 38: 949-964.

Wilkerson, F.P., R.C. Dugdale, V.E. Hogue, and A. Marchi. 2006. Phytoplankton blooms and nitrogen productivity in San Francisco Bay. Estuaries and Coasts 29: 401-416.

York, J.K., B.A. Costas, and G.B. Mcmanus. 2011. Microzooplankton grazing in green water-results from two contrasting estuaries. Estuaries and Coasts 34: 373-385.

York, J.K., G.B. McManus, W.J. Kimmerer, A.M. Slaughter, and T.R. Ignoffo. 2013. Trophic links in the plankton of a large temperate estuary: top-down effects of a nonnative copepod assemblage. Estuaries and Coasts. doi:10.1007/s12237-013-9698-9 